\title{
Tetrapocillon (Demospongiae: Poecilosclerida: Guitarridae) in Australia, with the description of a new species
}

\author{
J. Fromont ${ }^{1}$, B. Alvarez², O. Gomez' and E. Roberts ${ }^{2}$ \\ 'Department of Aquatic Zoology, Western Australian Museum, Locked Bag 49, Welshpool DC, \\ Western Australia 6986, Australia. \\ ${ }^{2}$ Museum and Art Gallery of the Northern Territory, PO Box 4646, Darwin, Northern Territory 0801, \\ Australia.
}

\begin{abstract}
Tetrapocillon patbergquistae sp. nov. is described from Australia. The new species forms thick encrustations to low mounds, it has a soft and fragile texture, and is distinguished from other species of the genus by the presence of two different size classes of tetrapocilli and by small spiny isochelae. Two species, T. novaezealandiae Brøndsted and T. minor Pulitzer-Finali are reported from Australia for the first time, and are redescribed with reference to type and new material. A neotype is designated for $T$. novaezealandiae. The only other presently recognized extant species worldwide, T. kurushimensis Tanita and T. atlanticus Van Soest are discussed in relation to the Australian species.
\end{abstract}

KEYWORDS: taxonomy, systematics, sponges, Porifera.

\section{INTRODUCTION}

The sponge genus Tetrapocillon was established by Brøndsted (1924) for the species T. novaezealandiae, a temperate species recorded from New Zealand. The species was later found in South Africa (Lévi 1963), and was redescribed with additional locality records in New Zealand (Bergquist and Fromont 1988), but had not been recorded from elsewhere, including Australia. A further three species have been recorded in the genus: Tetrapocillon kurushimensis Tanita, 1961 from Kurushima Strait, Seto Sea, Japan; T. atlanticus Van Soest, 1988 from the Cape Verde Archipelago, SE Atlantic Ocean; and T. minor Pulitzer-Finali, 1993 from Zanzibar, east Africa.

Tetrapocillon has a global distribution with one temperate species $T$. novaezealandiae known from the southern hemisphere, and three tropical species. Of the tropical species, T. atlanticus and T. kurushimensis occur in the northern hemisphere, while T. minor was found in the Indian Ocean (southern hemisphere), and more recently in Laing Island, Papua New Guinea (Pulitzer-Finali 1996). The distributions of at least two of the species, Tetrapocillon novaezealandiae and $T$. minor are disjunct, with no connecting records between New Zealand and South Africa for the former, and Zanzibar and Papua New Guinea for the latter.

Prior to this study, the genus was known to be represented in Australia only from three figures of tetrapocilli from an undescribed sponge collected in Fremantle, Western Australia (Bowerbank 1864).
Bowerbank did not formerly name the material he examined, only commenting on the unusual microscleres present. A later report of Tetrapocillon novazealandiae from Victoria and Tasmania (Hooper and Wiedenmayer 1994) was an error (J. Hooper, pers. comm.). This paper reports the occurrence of the genus Tetrapocillon in Australia for the first time in both tropical and temperate localities. A new species is described and new locality records are given for $T$. novaezealandiae and T. minor.

\section{MATERIALS AND METHODS}

Preserved material from various museums (listed at the end of this section) was examined during the course of this study. Newly collected specimens were preserved in $70 \%$ ethanol. Skeletal structure and spicule morphology were examined using light microscopy and scanning electron microscopy (SEM). Spicules were prepared by boiling small pieces of sponge (including the ectosome and choanosome) in concentrated nitric acid, followed by two consecutive washes with both distilled water and absolute alcohol. The resulting spicule extracts were dried on a glass slide and mounted in Shandon EZ-Mount (Thermo Electron Corporation). Spicule dimensions were determined by measurement of 20 randomly selected spicules per specimen using an eyepiece graticule with an Olympus BX50 or Leica DME microscope. Clean spicules were spread on coverslips attached to SEM stubs, dried at $70^{\circ} \mathrm{C}$ and sputter coated with gold prior to examination with a JEOL JSM 5610LV scanning microscope, operating 
between 15-21 kV. Images were recorded electronically.

The skeleton was prepared for examination by cutting a representative section at right angles to the surface of the sponge. The section was dehydrated through an ascending ethanol series, cleared in Histolene (Fronine Laboratory Supplies) and infiltrated in paraffin wax (Shandon Histoplast) using an automatic tissue processor on a nine hour cycle. The sponge tissue was further infiltrated with paraffin under a vacuum of $635 \mathrm{~mm} \mathrm{Hg}$ for $30 \mathrm{~min}$ prior to embedding. Blocks were sectioned at $90 \mu \mathrm{m}$ thickness with a Leitz slide microtome, and section rolling was eliminated by placing filter paper, moistened with distilled water, on top of the paraffin block. Sections were placed on a glass slide smeared with egg albumin for adhesion, dried overnight at $60^{\circ} \mathrm{C}$, and dehydrated in two changes of Histolene. Sections were mounted in Shandon EZ-Mount and examined using light microscopy. Images were recorded with a Leica DFC420 camera on a Leica DME microscope and saved electronically.

The specimens examined for this study are lodged in the following institutions: Coral Reef Research Foundation, Palau (CRRF, specimens prefixed with $0 \mathrm{CDN}$ and 0M9H codes), Museo Civico di Storia Naturale, Genova, Italy (MSNG); Museum and Art Gallery of the Northern Territory, Darwin, Australia, formerly Northern Territory Museum (NTM); Museum of New Zealand Te Papa Tongarewa, Wellington, New Zealand (NMNZ); Showa Memorial Institute, National Museum of Nature and Science, Ibaraki, Japan (NSMT); Queensland Museum, Brisbane, Australia (QM); Western Australian Museum, Perth, Australia (WAM); Zoological Museum of the University of Amsterdam,
The Netherlands (ZMA); and Zoological Museum, State National History Museum of Denmark, University of Copenhagen, Copenhagen, Denmark (ZMUC).

\section{SYSTEMATICS}

Order Poecilosclerida Topsent, 1928

\section{Suborder Mycalina Hajdu, Van Soest and Hooper, 1994}

\section{Family Guitarridae Dendy, 1924}

\section{Tetrapocillon Brøndsted, 1924}

\section{TYPE SPECIES}

Tetrapocillon novaezealandiae Brøndsted, 1924 by monotypy.

\section{Tetrapocillon novaezealandiae Brøndsted, 1924}

Figures 1, 2A, 3-4

Tetrapocillon novaezealandiae Brøndsted, 1924: 456, figure 15; Lévi 1963: 25, figure 26, plate 2 figure J; Bergquist and Fromont 1988: 46, plate 17 figures E, F, plate 18 figures A, B, Hooper and Wiedenmayer 1994: 179.

\section{MATERIAL EXAMINED}

\section{Neotype}

New Zealand: Auckland: single specimen fragmented into 9 pieces, Anchor Bay, Tawaharanui Peninsula, East of Warkworth, $36^{\circ} 22.2^{\prime} \mathrm{S}, 174^{\circ} 50.50^{\prime} \mathrm{E}, 5 \mathrm{~m}$ depth,

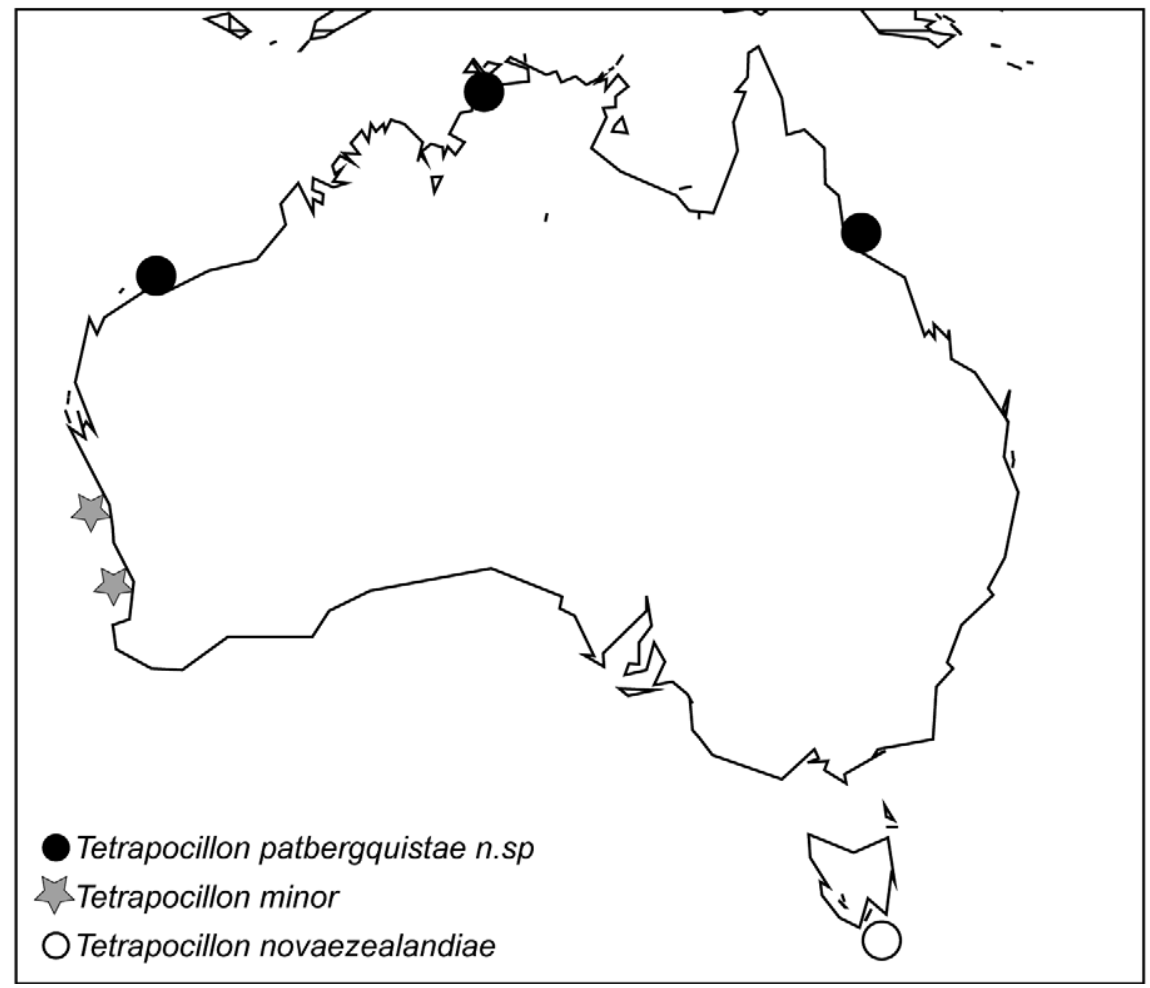

FIGURE 1 Map of distributions of Australian species of Tetrapocillon. 


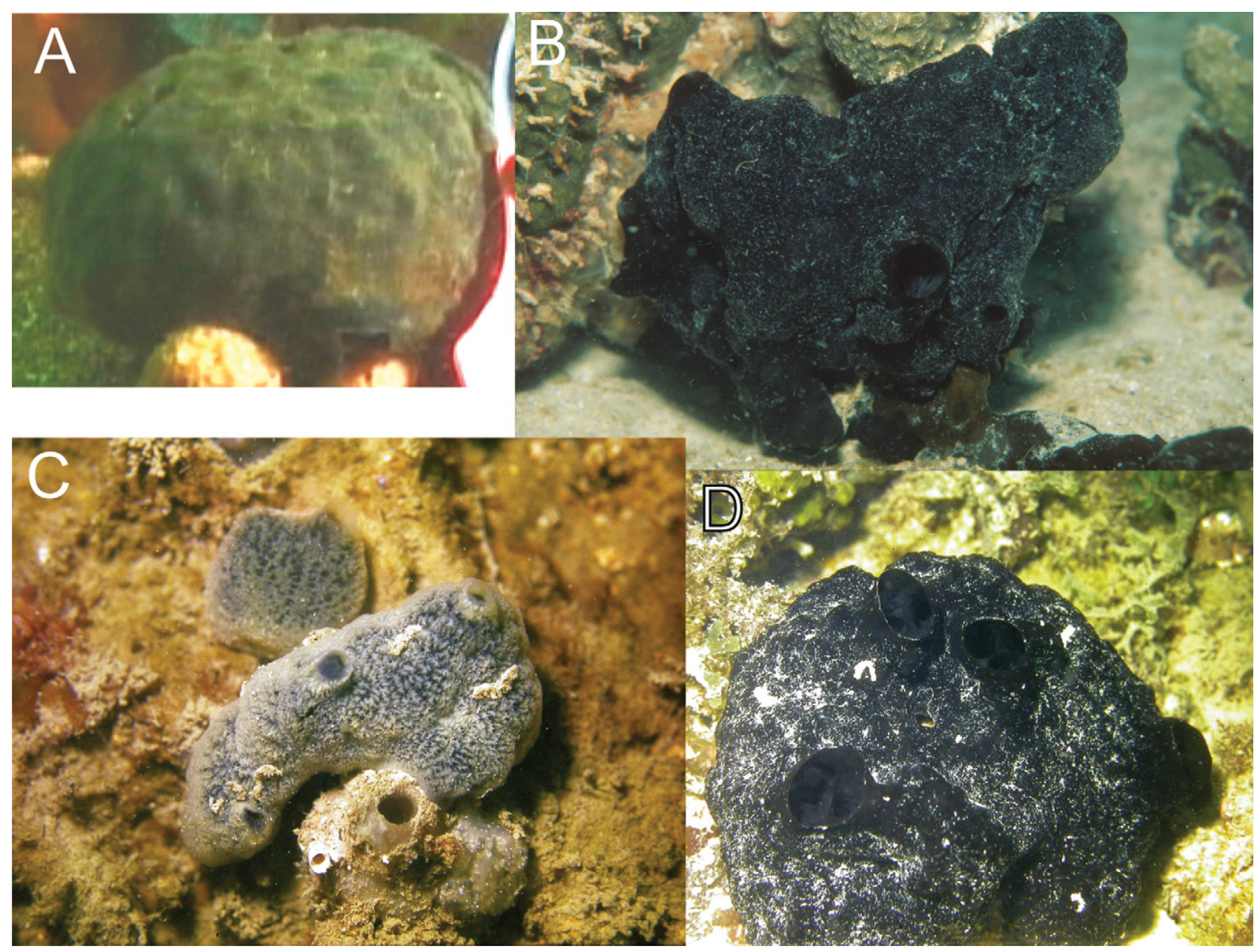

FIGURE 2 A, Tetrapocillon novaezealandiae, specimen from Tasmania in situ (QM G321493); B, T. minor, specimen from Zanzibar (0CDN3554-W) in situ; C, holotype of T. patbergquistae (NTM Z005698) in situ; D, specimen of T. patbergquistae from Nightcliff Bommies, Darwin Harbour population. Photos: A, Aquenal Pty Ltd; B, Patrick Colin; C, Belinda Alvarez; D, Huy Nguyen.

collectors, date of collection and method of collection unknown (NMNZ PO.252).

\section{Other material}

South Africa: Western Cape Province: 1 piece, station KNY 17, channel west of Leisure Isle, Knysna Estuary, $34^{\circ} 04.16^{\prime} \mathrm{S}, 23^{\circ} 03.18^{\prime} \mathrm{E}, 12 \mathrm{~m}$ depth, collectors and method of collection unknown, 15 July 1947 (fragment from ZMUC collections).

Australia: Tasmania: 1 specimen, Simpson Point, Tasmania, $43^{\circ} 14.38^{\prime} \mathrm{S}, 147^{\circ} 17.24^{\prime} \mathrm{E}, 12 \mathrm{~m}$ depth, A. Davey and R. Mawbey, SCUBA, 7 September 2004 (QM G321493).

\section{DIAGNOSIS}

Tetrapocillon novaezealandiae is characterised by being thickly encrusting and tending to form small, discrete flat mounds, a dark brown to black surface and yellow to orange interior, microscleres consisting of two sizes of tetrapocilli (mean $31 \times 23$ and $49 \times 31 \mu \mathrm{m}, \mathrm{n}$ $=80$ ), isochelae of two forms (mean $12.5 \mu \mathrm{m}, \mathrm{n}=40$ ), and slightly undulating styles as megascleres (mean 289 x $5.5 \mu \mathrm{m}, \mathrm{n}=40$ ). Skeleton a loose reticulation, with spicule brushes at the surface.

\section{DESCRIPTION}

Habitus as in Figures 2A and 3A. Thick encrusting to low mound with a smooth surface. Dimensions of New Zealand specimen (largest piece): length $400 \mathrm{~mm}$, width $400 \mathrm{~mm}$, thickness less or equal to $40 \mathrm{~mm}$. Oscules apical, rare, small, less than $0.5 \mathrm{~mm}$ wide in preserved sponges. Surface smooth, velvety and granular in appearance. Texture soft and slightly compressible, more firm and pliable in the dermal region, more crumbly mesohyl. Colour: in the live state jet black exterior, bright orange-yellow interior; in ethanol black to brownblack exterior, light brown interior.

General organization: (Figure 3B). Ectosomal skeleton up to $550 \mu \mathrm{m}$ in thickness includes a pigmented layer with numerous dark pigmented cells. Brushes of styles forming apical fans project approximately 30 $\mu \mathrm{m}$ beyond the surface. Primary tracts $(\sim 50 \mu \mathrm{m}$ thick $)$ branch beneath the surface forming two or three spicule brushes. Choanosome consists of irregular tracts of styles beneath the ectosome becoming an haphazard reticulation internally. Tetrapocilli of both sizes are 
throughout the choanosome and around canals.

Spicules (Figures 3C, 4A-D). Megascleres are slender styles that tend towards subtylostylote forms (Figure 3C), of uniform size, usually slightly undulating, with long tapering points (Table 1). Microscleres include two sizes of tetrapocilli: small category is compact with relatively thick plates covered with spines up to $0.5 \mu \mathrm{m}$ long, and central plates usually completely joined in the neotype (Figure 4A), but occasionally not joined at the edges (e.g. QM G321493); large category with splayed and thinner plates also covered with tiny or rudimentary spines along the internal edges (Figure 4B). Palmate acanthoisochelae (i.e. following the terminology of Lerner et al. [2004] for spiny isochelae) of two forms of similar length but different widths. One form with a relatively shorter and slightly curved shaft, uniformly covered with clusters of fine spines (Figure 4C). Second form with a long and straight shaft, irregularly covered with spines in clusters, supporting helmet-like alae irregularly covered with spines approximately $0.5 \mu \mathrm{m}$ long. Short or rudimentary spines aggregated in clusters of irregular shape along the edges of the alae (Figure 4D).
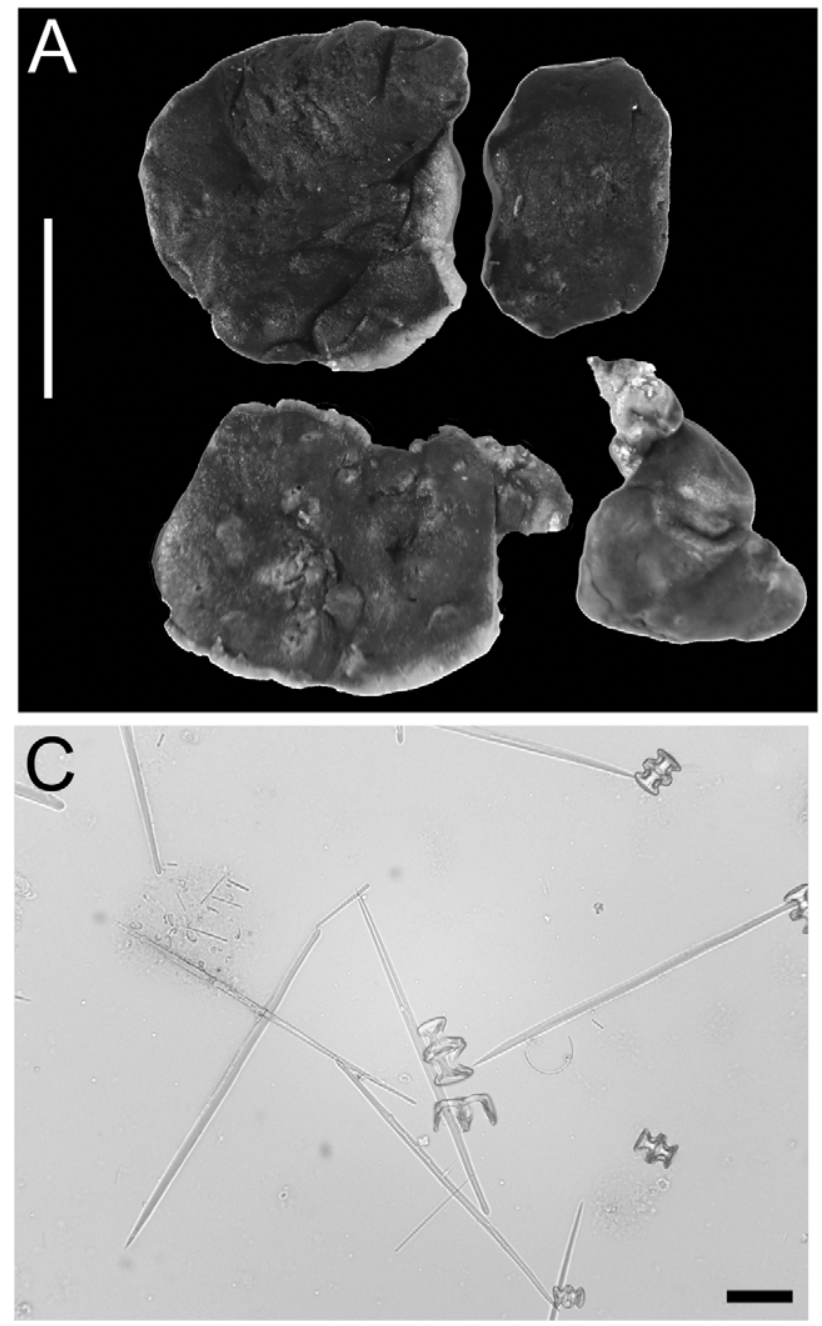

\section{REMARKS}

The type specimen of Tetrapocillon novaezealandiae is lost although extensive searches in the ZMUC have been undertaken at various times in the last decade to find it. Only a single specimen was examined when the species was described, and no microscope slides or any parts of this specimen now exist (O. Tendal, pers. comm.). Brøndsted did not label his specimens and did not make permanent spicule slides, and the material was not loaned to other researchers or institutes (O. Tendal, pers. comm.). Brøndsted's specimens were stored in a single drum in formalin in the ZMUC, which has caused complete dissolution of some specimens (P. Bergquist, pers. comm.), and this is likely to have contributed to the loss of the holotype of $T$. novaezealandiae. New characters found in this study, two sizes and forms of tetrapocilli and two forms of isochelae, are specific to $T$. novaezealandiae and were not reported by Brøndsted (1924). To clarify the specific characters for this species, and to ensure a sound taxonomic base for further work we here designate a New Zealand specimen (NMNZ PO.252) as neotype. Establishment

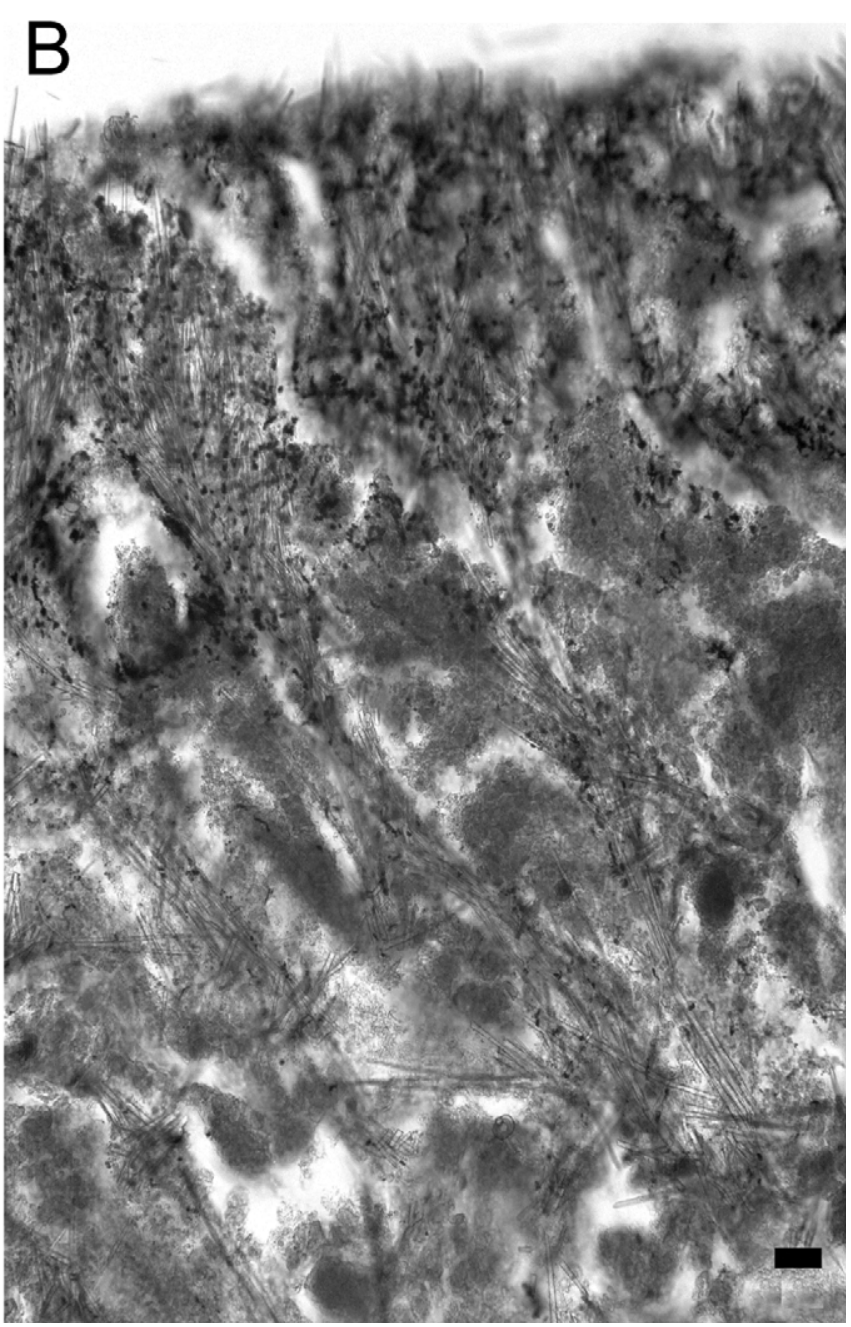

FIGURE 3 Tetrapocillon novaezealandiae: A, photograph of neotype (NMNZ PO.252), scale bar = $2 \mathrm{~cm}$; $\mathrm{B}$, microphotograph of skeleton, scale bar $=100 \mu \mathrm{m} ; \mathrm{C}$, microphotograph of dissociated spicules, scale bar = $50 \mu \mathrm{m}$. 


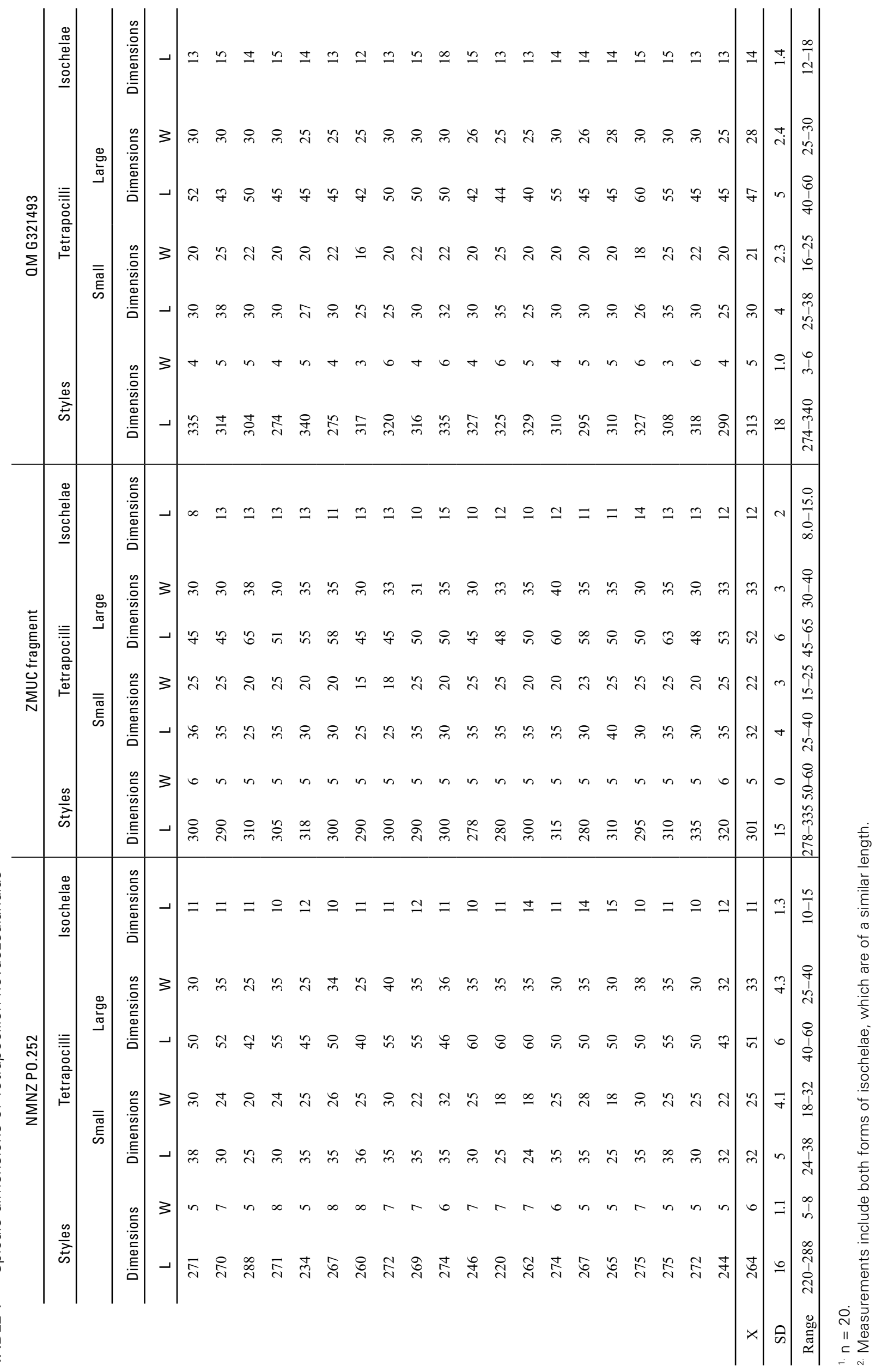



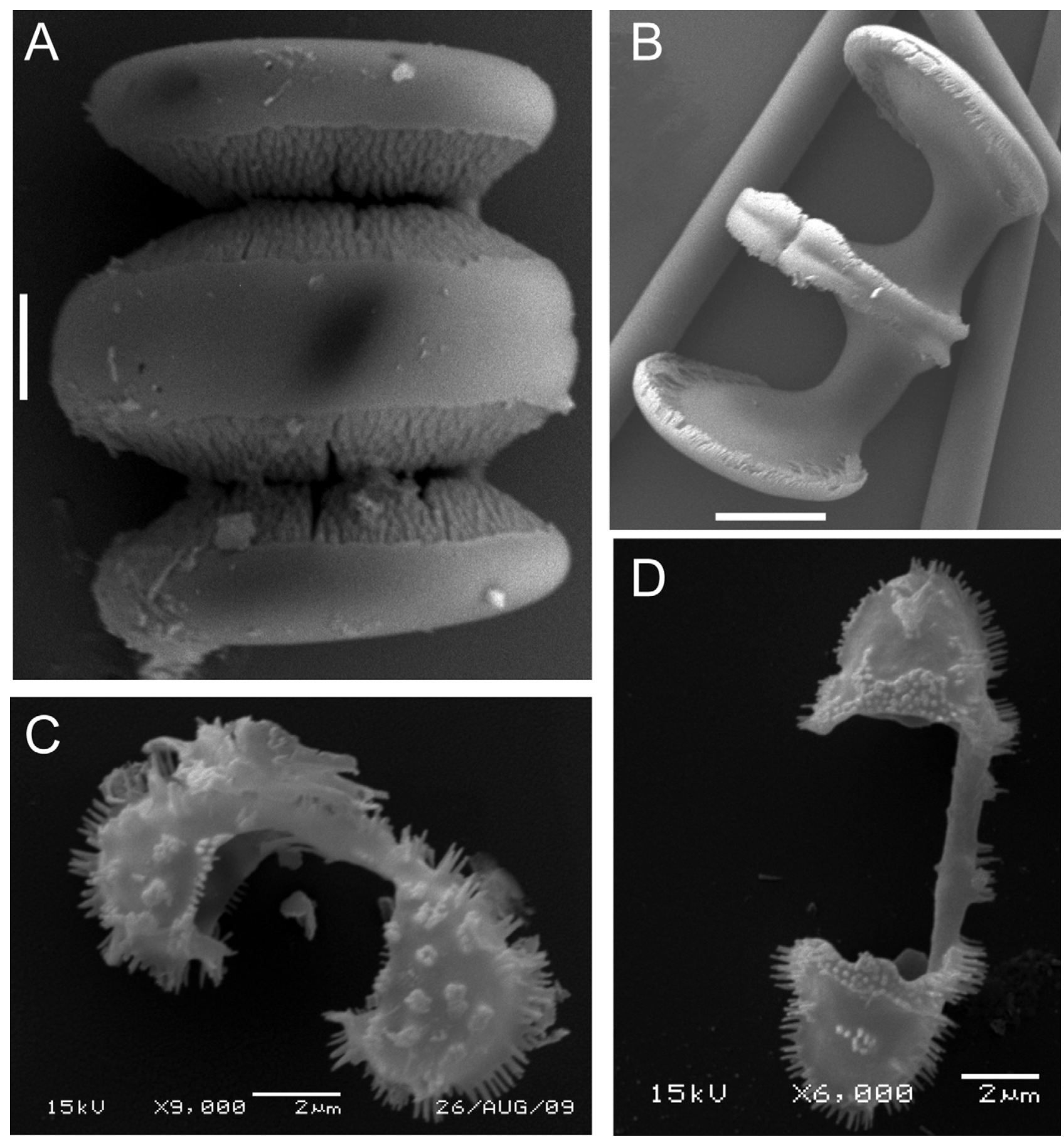

FIGURE 4 Tetrapocillon novaezealandiae, SEM photographs of microscleres: A, small, regular tetrapocilli (NMNZ PO.252), scale bar $=5 \mu \mathrm{m}$; B, large, splayed tetrapocilli (QM G321493), scale bar $=10 \mu \mathrm{m}$; C, thick isochelae (NMNZ PO.252); D, thin isochelae (QM G321493).

of a neotype from near the type locality in New Zealand provides a specimen to assist with future research into the distribution of this species which has been found throughout the southern ocean, and provides material for any future genetic analyses. The neotype specimen was collected at Tawaharanui Peninsula (Hauraki Gulf) in the shallow subtidal (5 $\mathrm{m}$ depth), which is 65 nautical miles north of the type locality, Slipper Island, south-east of the Hauraki Gulf, off Pauanui Beach ( $\left.37^{\circ} 2^{\prime} 56.52^{\prime \prime} \mathrm{S}, 175^{\circ} 56^{\prime} 27.19^{\prime \prime} \mathrm{E}\right)$. The holotype was collected intertidally. The original type specimen was smaller and thinner (30 × 25 × 3 mm; Brøndsted 1924) than the neotype described here (400 x $400 \times 40 \mathrm{~mm})$, and specimens described by Bergquist and Fromont (1988). A second specimen from New Zealand (NMNZ PO.319) is dry and consists of two small pieces collected from Great Barrier Island, Hauraki Gulf (B. Marshall, NMNZ, pers. comm.). The neotype is a reproductive female with developing oocytes.

We were not able to examine Lévi's material from the Iziko South African Museum, Cape Town, but did examine a fragment deposited in the Zoological Museum, Copenhagen. Lévi (1963) figured mainly the larger tetrapocilli with splayed terminal plates in 
his redescription of Tetrapocillon novaezealandiae. Brøndsted (1924) had considered these to be growth phases of the same spicule, with the larger size being the mature form. These two different forms can be seen in all specimens of $T$. novaezealandiae examined here from New Zealand, Australia and South Africa. This is a widespread Southern Ocean distribution for this species, and only genetic studies on each of the populations could determine if they are truly conspecific. Until these studies are undertaken we have no evidence to split this species which has consistent morphological characters in all specimens examined.

The isochelae found in this species have two different morphologies and are larger $(12.5 \mu \mathrm{m})$ than the isochelae found in the species described below. Bergquist and Fromont (1988) noted that oscules are visible in the live state, flush with the surface, measuring $0.5-0.8 \times 0.2-$ $0.4 \mathrm{~mm}$, but that they tend to disappear on preservation. Oscules were rare and small in the preserved material we examined.

\section{DISTRIBUTION AND HABITAT}

Tetrapocillon novaezealandiae is found in New Zealand, South Africa and Australia in cool temperate localities. It is a shallow water species found intertidally to $15 \mathrm{~m}$ depth on rocky reefs. This species has not been found above $33^{\circ}$ South.

\section{Tetrapocillon minor Pulitzer-Finali, 1993}

Figures 1, 2B, 5, 6

Tetrapocillon minor Pulitzer-Finali, 1993: 296, figure 27; Pulitzer-Finali 1996: 119.

\section{MATERIAL EXAMINED}

\section{Holotype}

Tanzania: Zanzibar Urban/West: 2 slides (skeletal section and dissociated spicules, MSNG 48312), Chapani Bay, $6^{\circ} 08.0^{\prime} \mathrm{S}, 39^{\circ} 11.0^{\prime} \mathrm{E}, 2-3 \mathrm{~m}$ depth, G. Pulitzer-Finali, 8 February 1974 (MSNG 48312; remainder of specimen lost, Guiliano Doria, pers. comm., but 2 slides intact).

\section{Other material}

Tanzania: Zanzibar Urban/West: 1 specimen, station Zanzibar 02, Morogo Reef, back reef 6 miles west of Zanzibar town, $6^{\circ} 11.30^{\prime} \mathrm{S}, 39^{\circ} 07.70^{\prime} \mathrm{E}, 15 \mathrm{~m}$ depth, Coral Reef Research Foundation, SCUBA, 19 January 1996 (0CDN3554-W). Papua New Guinea: Madang Province: 1 specimen, Laing Island, $4^{\circ} 13.75^{\prime} \mathrm{S}$, $144^{\circ} 56.58^{\prime} \mathrm{E}, 15 \mathrm{~m}$ depth, G. Pulitzer-Finali, 13 August 1986 (MSNG 55060). Madagascar: Antsiranana Province: 1 specimen, Nosy Bé, Point de la Fièvre, $13^{\circ} 25.25^{\prime} \mathrm{S}, 48^{\circ} 17.3^{\prime} \mathrm{E}, 1 \mathrm{~m}$ depth, J.H. Stock, 1 May 1964 (ZMA Por.15263). Australia: Western Australia: 3 specimens, North Mole, Fremantle, $32^{\circ} 02.95^{\prime} \mathrm{S}$, $115^{\circ} 43.78^{\prime} \mathrm{E}, 5 \mathrm{~m}$ depth, J. Fromont and party, SCUBA, 7 September 2004 (WAM Z21262-Z21264); 1 specimen, station JWAM28/T2, south of Leander, Dongara, $29^{\circ} 16.77^{\prime} \mathrm{S}, 114^{\circ} 54.61^{\prime} \mathrm{E}, 8 \mathrm{~m}$ depth, J. Fromont and party,
SCUBA, 15 March 2006 (WAM Z40625).

\section{DIAGNOSIS}

Tetrapocillon minor is characterised by being encrusting to lobate and spreading, delicate and soft, tearing and fragmenting easily, with black exterior and grey to yellow interior; microscleres two forms of tetrapocilli of equivalent size (mean $24 \times 17 \mu \mathrm{m}, \mathrm{n}=80$ ), tiny isochelae up to $5 \mu \mathrm{m}$ long, and very thin, slightly undulating styles as megascleres (mean $261 \times 3 \mu \mathrm{m}, \mathrm{n}=$ $80)$. Skeleton an irregular reticulation, with occasional wispy spicule brushes at the surface.

\section{DESCRIPTION}

Habitus as in Figures 2B, 5A. Thin encrusting to lobate or spreading with smooth glossy surface. Dimensions of Dongara specimen (WAM Z40625): length $600 \mathrm{~mm}$, width $400 \mathrm{~mm}$, thickness $10 \mathrm{~mm}$ or less. Oscules large, apical, rare; not apparent in preserved sponges. Surface smooth and glossy. Texture firm and compressible or soft and friable in fragmented specimens. Colour: in the live state, black exterior, greenish yellow or yellow orange interior, in ethanol black to black-brown exterior, light fawn to medium grey or brown interior.

General organization (Figure 5B): Ectosomal region consists of a thin band ( $\sim 10 \mu \mathrm{m}$ wide) of thickened mesohyl containing pigment cells. Primary multispicular tracts $(\sim 25 \mu \mathrm{m}$ thick) at right angles beneath surface, in subectosomal region end in wispy brushes of styles. Choanosome irregularly reticulate, abundant styles arranged haphazardly, pigment cells throughout. Tetrapocilli uncommon throughout mesohyl of type slides and Western Indian Ocean material, but common around internal canals in Australian specimens. Basally, the type skeletal slide has thickened mesohyl with occasional curved styles. The specimen (0CDN3554-W) collected from Zanzibar on 19 January 1996 was a reproductive female with orange eggs.

Spicules: (Figures 5C, 6A-F). Megascleres: very thin styles with long tapering points, straight, occasionally curved or slightly undulating and wispy (Table 2). Microscleres: two forms of tetrapocilli, regular forms are common and compact with relatively thick plates (Figure 6A), splayed forms, with thin plates, are rare (Figure 6B). Isochelae, transitional series from palmate acanthoisochelae with short, thin shaft and alae forming shallow caps (Figure 6C, right arrow) to rudimentary acanthoisochelae with perforated alae (Figure 6E-F), to $\mathrm{C}$-shaped where alae are almost non-existent (Figure 6C, upper arrow), or occasionally circular where rudimentary alae are almost connected centrally (Figure $6 \mathrm{D})$, with clusters of spines. Isochelae are rare, fragile, frequently broken in preparations, tiny, up to $5 \mu \mathrm{m}$ long, only visible with SEM.

\section{REMARKS}

The majority of the type specimen of Tetrapocillon minor was lost during a flood of Genova in 1992 (Borgo 


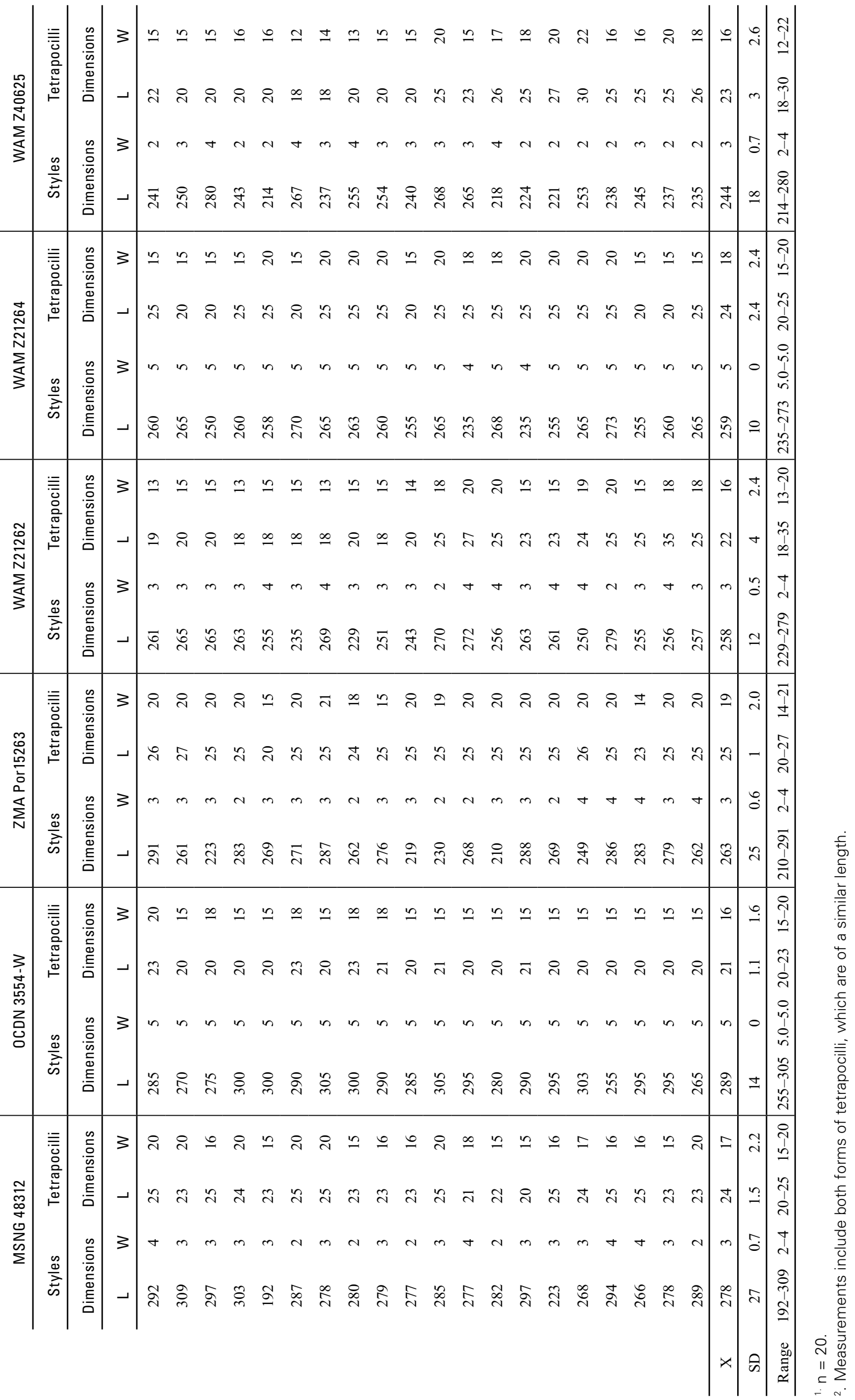




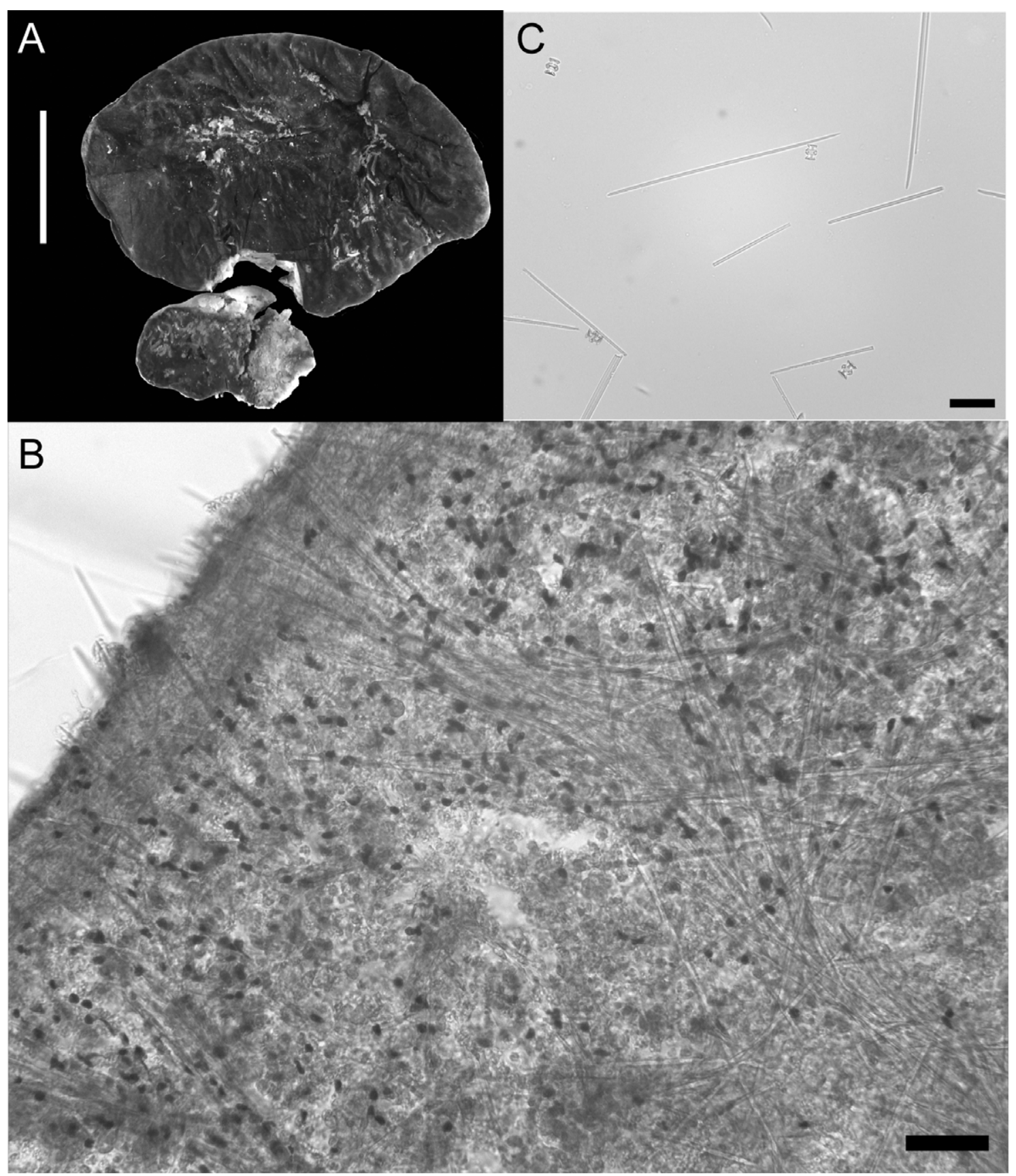

FIGURE 5 Tetrapocillon minor: A, photograph of specimen from Dongara (WAM Z40625), scale bar = $2 \mathrm{~cm}$; $B$, microphotograph of skeleton of North Mole specimen (WAM Z21262), scale bar $=50 \mu \mathrm{m}$; C, spicules of North Mole specimen (WAM Z21262), scale bar $=50 \mu \mathrm{m}$.

et al. 1998). A thick section of the skeleton and a slide of dissociated spicules made from the type specimen prior to the flood were examined in this study and enabled the description of the skeletal layout, not provided in PulitzerFinali's original description. Pulitzer-Finali (1993) described the spicules as oxeas 'with one end sharp, the other dull', but they are clearly very thin styles.

This species is characterized by the presence of two forms of tetrapocilli that are identical in size, with the regular right-angled form clearly more common than the splayed form. Other species of Tetrapocillon examined here have two forms of tetrapocilli in different size categories. Splayed tetrapocilli were figured by Pulitzer-Finali (1993) but were not mentioned in his type description.

The small isochelae were not seen with light microscopy, but were consistently seen with SEM in material of this species and are characteristic for Tetrapocillon minor. These spicules are rare, very fragile and were frequently broken in SEM preparations. They form a morphological transition series from palmate acanthoisochelae with complete alae to reduced alae with varying degrees of perforation, which can become rudimentary to the extent of looking like spiny reinforced sigmas.

Boury-Esnault et al. (1993) reported isochelae-like spicules with greatly reduced alae in Guitarra fimbriata 

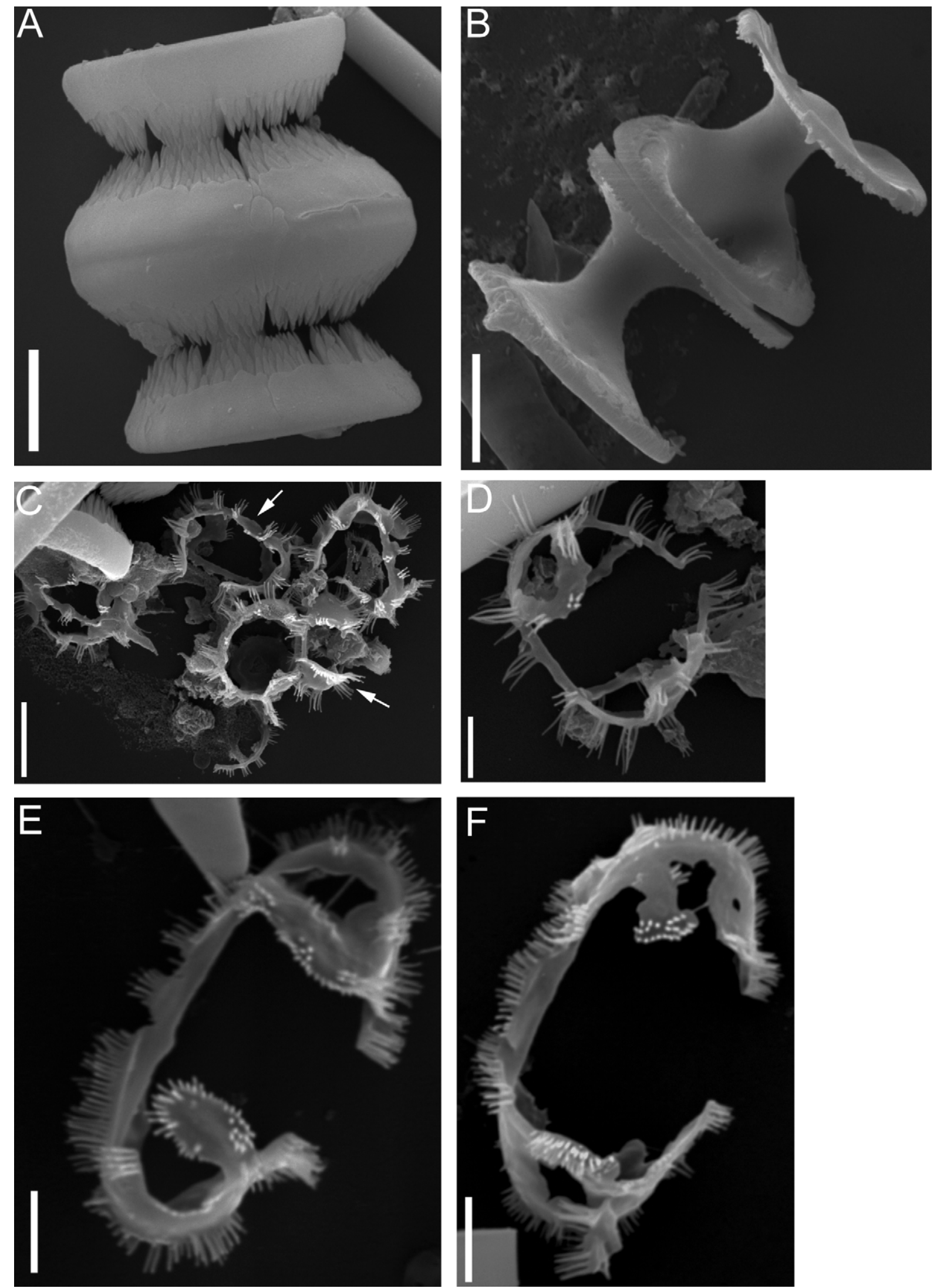

FIGURE 6 Tetrapocillon minor: A, regular tetrapocilli (OCDN3554W), scale bar $=5 \mu \mathrm{m} ; \mathrm{B}$, splayed tetrapocilli (WAM Z21262), scale bar $=5 \mu \mathrm{m}$; C, cluster of isochelae, arrows indicating transitional forms (OCDN3554W), scale bar $=2 \mu \mathrm{m} ; \mathrm{D}$, almost circular isochelae with reduced alae (OCDN3554W), scale bar $=2 \mu \mathrm{m}$; E-F, rudimentary isochelae (WAM Z40625), scale bar $=2 \mu \mathrm{m}$. 
Carter, 1874. Carballo and Uriz (1998) described these spicules as spiny sigmoid isochelae in G. fimbriata and G. indica Dendy, 1916. These isochelae have reduced alae and consequently look like spiny sigmas. Lerner et al. (2004) reported spiny isochelae in G. sepia Lerner, Hajdu, Custódio and Van Soest, 2004, where the frontal alae nearly joined giving a circular appearance to the spicule. We have found rudimentary acanthoisochelae in Tetrapocillon minor of a similar sigmoid form to those described in some species of Guitarra. The alae are rudimentary (Figure 6E, F) to non existent (Figure $6 \mathrm{C}$, upper arrow), to almost connected centrally (Figure 6D) in T. minor. This transition series from rudimentary to non-existent alae has prompted us to describe these spicules as isochelae rather than sigmas.

Pulitzer-Finali (1996) described a specimen of Tetrapocillon minor from Papua New Guinea. This material (MSNG 55060) is a thin brown encrustation 18 x 15 x $1.5 \mathrm{~mm}$ thick. No dark pigment cells occur in the mesohyl which are clearly visible in the type slide and other specimens examined of this species. In addition the styles are consistently contort and wavy. Such spicule morphologies were rare in the type slides and this specimen does not belong in T. minor.

Spicules in specimens of Tetrapocillon minor are consistently thin styles, one size range and two forms of tetrapocilli, and tiny isochelae. Neither $T$. novaezealandiae nor $T$. patbergquistae have such thin styles and small rudimentary isochelae.

\section{DISTRIBUTION AND HABITAT}

Tetrapocillon minor is found in Tanzania, Zanzibar, Madagascar and the central west coast of Australia in warm temperate to sub-tropical localities. It was reported from Papua New Guinea by Pulitzer-Finali (1996) but we have examined this material and conclude that it is not conspecific with T. minor. This is a widespread Indian Ocean, shallow water, species found intertidally to $15 \mathrm{~m}$ depth on rock and coral reefs north of $32^{\circ}$ latitude.

\section{Tetrapocillon patbergquistae sp. nov.}

Figures 1, 2C, D, 7, 8

\section{MATERIAL EXAMINED}

\section{Holotype}

Australia: Northern Territory: 1 specimen, Middle Arm, Sand Island, Darwin Harbour, 12³5.291'S, $130^{\circ} 52.264^{\prime} \mathrm{E}, 5-8 \mathrm{~m}$ depth, B. Alvarez and party, SCUBA, 7 September 2003 (NTM Z005698).

\section{Paratypes}

Australia: Northern Territory: 1 specimen, Wickham Point, Darwin Harbour, $12^{\circ} 30.12^{\prime}$ S, $130^{\circ} 52.39^{\prime} \mathrm{E}, 5-8$ $\mathrm{m}$ depth, B. Alvarez and party, SCUBA, 15 September 2002 (NTM Z005204; 0M9H2296-N); 1 specimen, Nightcliff Bommies, off Nightcliff jetty, $12^{\circ} 22.751^{\prime} \mathrm{S}$, $130^{\circ} 50.116^{\prime} \mathrm{E}$, 5-8 $\mathrm{m}$ depth, M. Browne, SCUBA,
8 August 2003 (NTM Z005205; 0M9H2563-C); 3 specimens, Middle Arm, Sand Island, 12 $35.283^{\prime} \mathrm{S}$, $130^{\circ} 52.260^{\prime} \mathrm{E}, 7 \mathrm{~m}$ depth, B. Alvarez, 9 September 2004, (NTM Z004199-Z004200, WAM Z21999 [ex NTM Z004201]); Queensland: 1 specimen, inshore of Fantome Island, Great Barrier Reef, $18^{\circ} 24.43^{\prime} \mathrm{S}$, $146^{\circ} 30.26^{\prime} \mathrm{E}, 19 \mathrm{~m}$ depth, N.J. Pilcher, SCUBA, 6 June 1989 (QM G311114), on flat mud; Western Australia: 1 specimen, station 17, Wilcox Island, Dampier Archipelago, $20^{\circ} 27.09^{\prime} \mathrm{S}, 116^{\circ} 50.44^{\prime} \mathrm{E}$, intertidal, J. Fromont, 23 October 1998 (WAM Z3191); 1 specimen, station 20 Collier Rocks, Dampier Archipelago, $20^{\circ} 24.81^{\prime} \mathrm{S}, 116^{\circ} 50.68^{\prime} \mathrm{E}$, intertidal, J. Fromont, by hand, 24 October 1998 (WAM Z3241).

\section{DIAGNOSIS}

Tetrapocillon patbergquistae is characterised by being thickly encrusting to forming low mounds with a grey finely patterned to black smooth surface and greenyellow to orange-yellow colour internally. Consistency very soft, fragile, collapses and may fragment out of water, microscleres consist of two sizes of tetrapocilli (mean $30 \times 23 \mu \mathrm{m}$ and $54 \times 33 \mu \mathrm{m}, \mathrm{n}=80$ ), small isochelae 7-8 $\mu \mathrm{m}$ long, and megascleres are straight styles (mean 281 x $5 \mu \mathrm{m}, \mathrm{n}=80$ ). Skeleton irregularly reticulated with an incomplete ectosomal palisade.

\section{DESCRIPTION}

Habitus as in Figures 2C, D. Thick encrusting to low mounds. Individuals grow in patches of 70-200 $\mathrm{mm}$ diameter and $50 \mathrm{~mm}$ thick. Surface is smooth in black specimens or granular and finely marked by the reticulation of the choanosomal skeleton in grey specimens found at Sand Island. Oscules up to $5 \mathrm{~mm}$ in diameter with elevated membranous rims. Texture very soft and fragile; collapses completely out of water and may fragment. Consistency of Nightcliff, Fantome and Dampier specimens, very delicate and fragile; soft and inflated underwater. Sand Island specimens more compact and tough. Colour: live colouration black or grey (Sand Island specimens); green-yellow or orange yellow internally, grey-black throughout in ethanol.

General organization (Figure 7A, B). Ectosomal skeleton thin, forming an incomplete palisade. Choanosomal skeleton irregularly reticulated with round to polygonal meshes, becoming loose internally and obscured by pigment cells. Primary multispicular tracts diverge to surface, are nearly perpendicular in subectosomal region and end in spicule brushes forming a palisade.

Spicules (Figures 7C, D, 8). Megascleres: thin styles with hastate or angulate ends, always straight (Table 3). Microscleres: tetrapocilli abundant throughout the choanosome in two size categories. Smaller tetrapocilli approximately 29-31 $\mu \mathrm{m}$ long with plates thick and rounded, closely spaced and densely covered with tiny spines $(3-4 \mu \mathrm{m})$ on inner faces of plate; middle plate slightly thicker and wider (19-22 by $6 \mu \mathrm{m})$ than terminal plates $(16-19$ by $3-4 \mu \mathrm{m})$ (Figure $8 \mathrm{~A}$ ). Larger 

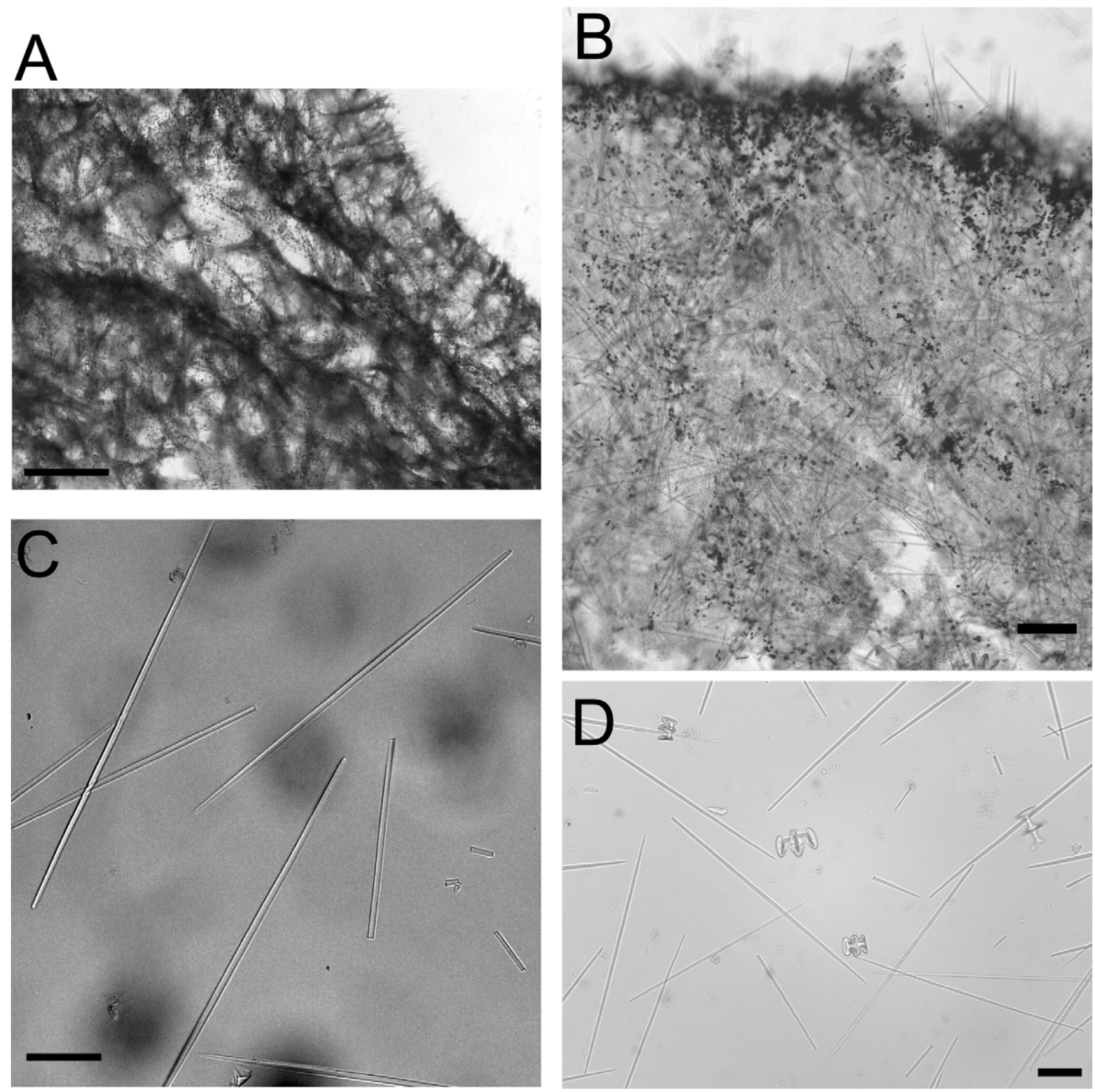

FIGURE 7 Tetrapocillon patbergquistae, skeletal organisation and spicules: A, holotype (NTM Z005698), scale bar = $500 \mu \mathrm{m}$; B, paratype (WAM Z3241), scale bar $=100 \mu \mathrm{m} ; \mathrm{C}$, megascleres of the holotype (NTM Z005698), scale bar $=50 \mu \mathrm{m} ; \mathrm{D}$, megascleres of paratype (WAM Z3241), scale bar $=50 \mu \mathrm{m}$.

splayed tetrapocilli, approximately $50-57 \mu \mathrm{m}$ in length with relatively thinner plates, widely spaced (approx. $15-18 \mu \mathrm{m}$ between plates), with inner faces covered with spines of different sizes $(1-6 \mu \mathrm{m})$; terminal plates, $26-$ $27 \mu \mathrm{m}$ long by $6-7 \mu \mathrm{m}$ thick, oriented $90-120$ degrees in relation to main axis; middle plate slightly longer (28-29 $\mu \mathrm{m})$ (Figures 8B, C). A smaller category of tetrapocilli, less than $20 \mu \mathrm{m}$ in length, with smooth plates is present in low frequency. Palmate acanthoisochelae, 7-8 $\mu \mathrm{m}$ long, with spined shaft $(<1 \mu \mathrm{m}$ thick $)$ and shallow concave alae covered regularly with discrete groups of spines, individual spines approximately $1 \mu \mathrm{m}$ long (Figures 8 D, E).

\section{REMARKS}

The acanthoisochelae do not form the deep concave cups present in isochelae of Tetrapocillon novaezealandiae and $T$. atlanticus. The tiny isochelae of $T$. minor have relatively thin shafts with rudimentary alae, a characteristic not seen in $T$. patbergquistae. However, the clusters of long spines in the latter two species place these warmer water species closer together than to the temperate $T$. novaezealandiae.

Tetrapocillon patbergquistae differs from all other species of Tetrapocillon found in Australia by size differences in the spicule complement. It has smaller acanthoisochelae than $T$. novaezealandiae $(7-8 \mu \mathrm{m}$ compared to $12.5 \mu \mathrm{m}$ ) but larger acanthoisochelae 


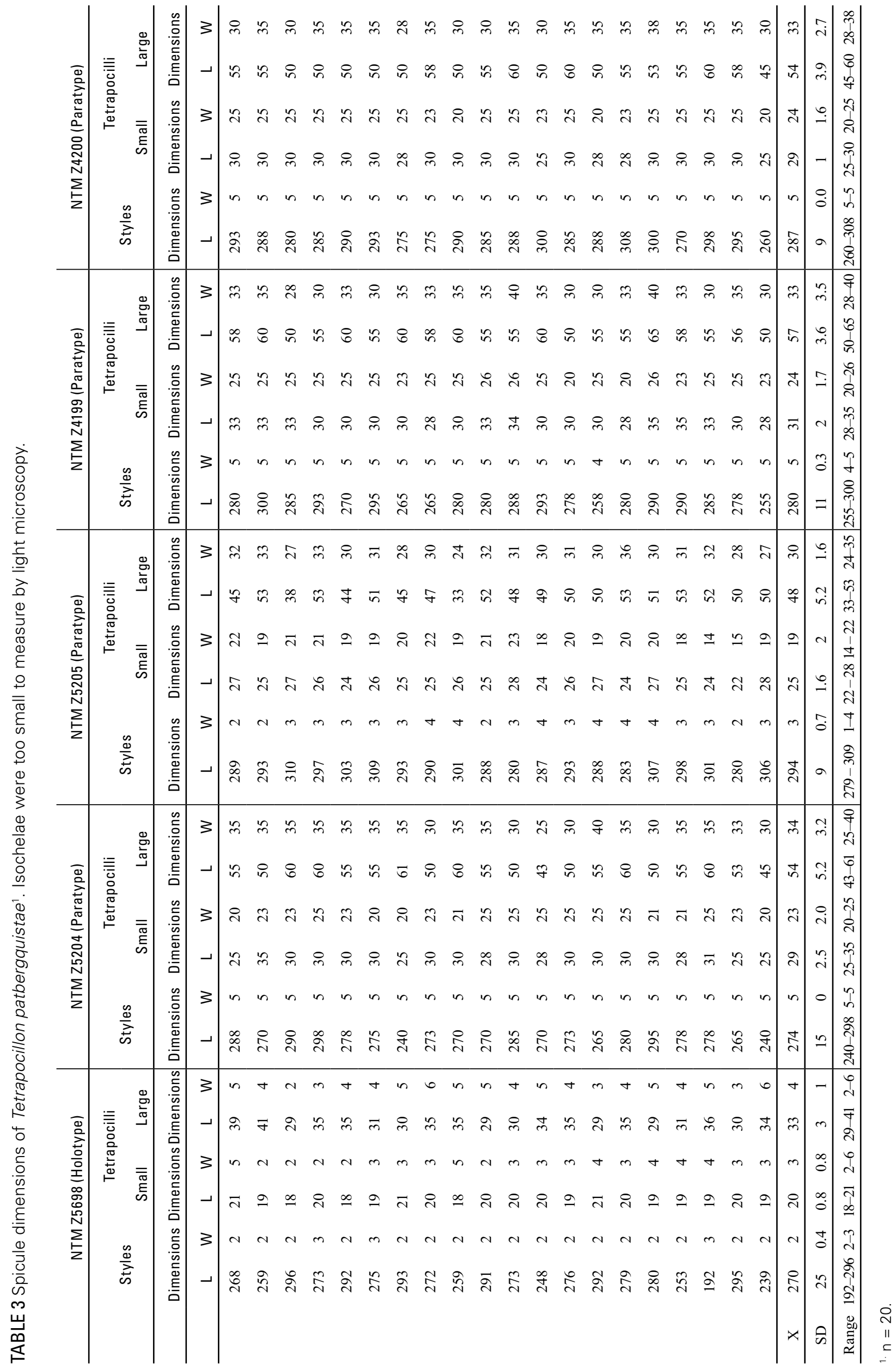




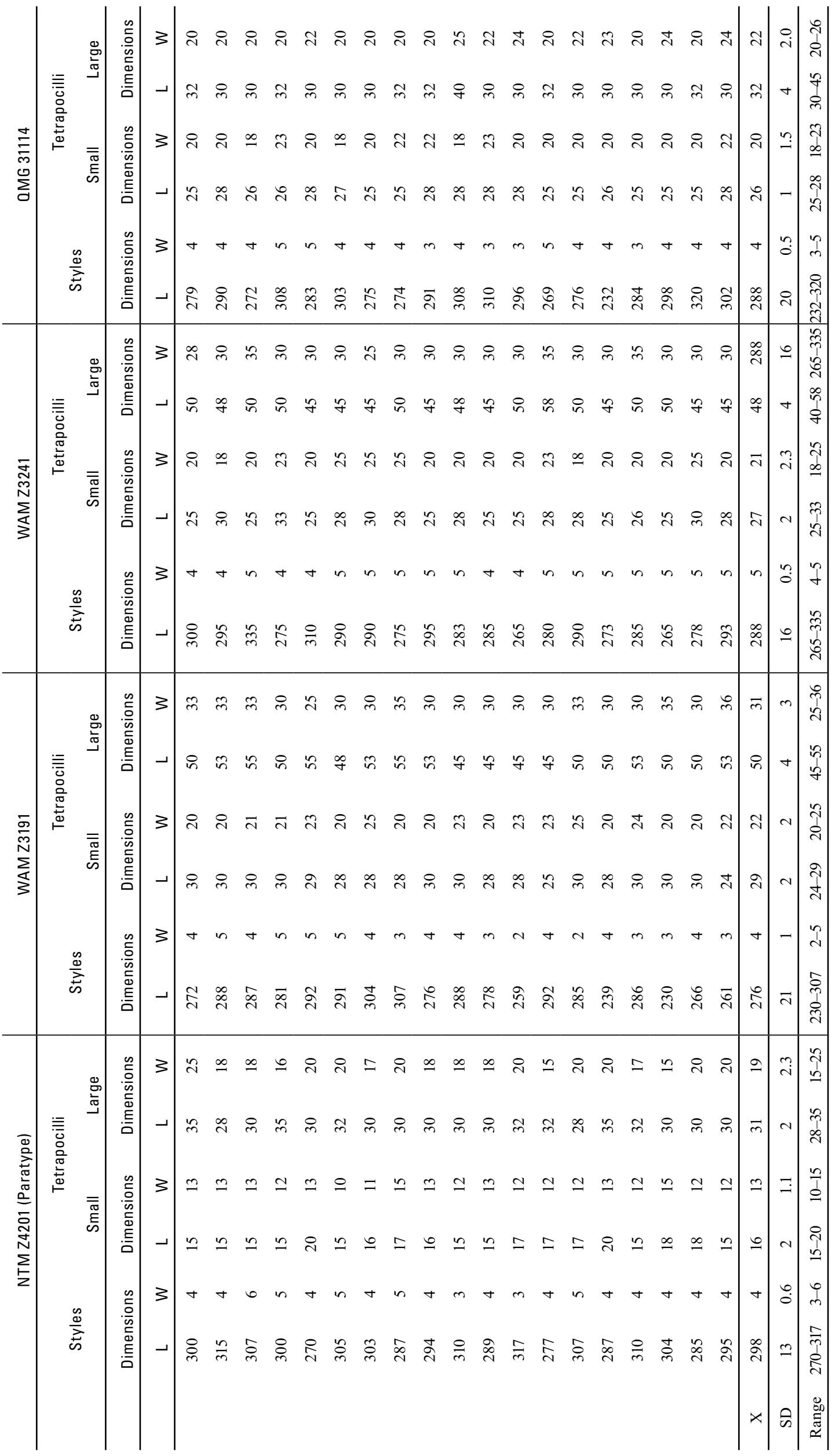



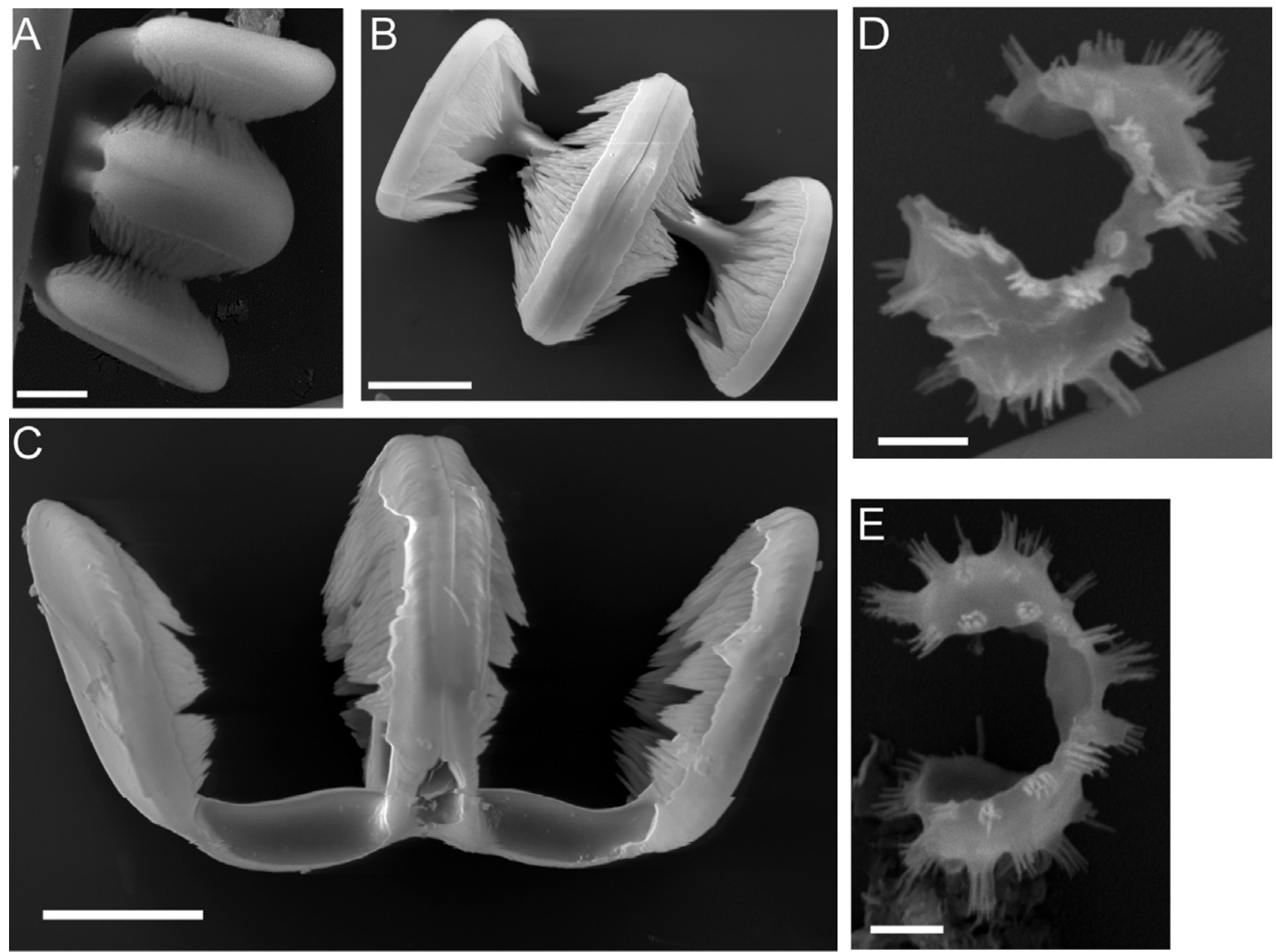

FIGURE 8 Tetrapocillon patbergquistae, microscleres: A, small tetrapocilli (NTM Z005698), scale bar = $5 \mu \mathrm{m}$; B-C, large tetrapocilli (NTM Z005205), scale bar = $10 \mu \mathrm{m}$; D-E, isochelae (NTM Z005698), scale bar $=2 \mu \mathrm{m}$.

than T. minor $(5 \mu \mathrm{m})$. The splayed tetrapocilli found in $T$. patbergquistae are larger than those in $T$. novaezealandiae and $T$. minor (mean $54 \mu \mathrm{m}$ long compared to mean $49 \mu \mathrm{m}$ and $24 \mu \mathrm{m}$ long respectively, see Tables 1-3). The styles are of a similar size to the styles of $T$. novaezealandiae ( $281 \times 5 \mu \mathrm{m}$ compared to $289 \times 5.5 \mu \mathrm{m})$ but consistently thicker than those in $T$. minor $(261 \times 3 \mu \mathrm{m})$. Tetrapocillon patbergquistae has only one form of acanthoisochelae compared to two forms in T. novaezealandiae, and the transitional series of rudimentary acanthoisochelae characteristic of T. minor.

At least three populations of this species were found during surveys conducted in Darwin Harbour during 2002-2003. The species has been found to date in three localities in the Northern Territory (Wickham Point, Sand Island - Middle Arm and Nightcliff Bommies) where it is relatively common. Dampier Archipelago specimens were found on intertidal reef amongst sponges, soft corals and hard coral species such as Acropora and fungiids. Both specimens collected from Dampier in October contained oocytes.

\section{DISTRIBUTION AND HABITAT}

Tetrapocillon patbergquistae is found in the Northern
Territory, northern Western Australia and Queensland, Australia. It is a tropical species occurring on rocky reef, mud and sand (NTM Z005204, Z005698, QM G311114) or coral heads, live coral, sand and rubble (NTM Z005205, WAM Z3191, Z3241), and occurs intertidally to $19 \mathrm{~m}$ depth.

\section{ETYMOLOGY}

This species is named in honour of Dame Professor Patricia Bergquist who pioneered modern sponge science in the Southern Hemisphere and particularly in Australasia, and who passed away on 9 September 2009.

\section{KEY TO AUSTRALIAN SPECIES OF TETRAPOCILLON}

1. Tetrapocilli present, in 2 forms but consisting of only 1 size. Tetrapocillon minor

Tetrapocilli present, 2 forms of 2 sizes. 2

2. Isochelae in 2 forms

Tetrapocillon novaezealandiae

Isochelae in 1 form......Tetrapocillon patbergquistae 


\section{DISCUSSION}

We report the first occurrence of Tetrapocillon in Australia and describe three species, the temperate $T$. novaezealandiae found across the Southern Ocean in New Zealand, Australia and South Africa, the warm temperate to sub-tropical Indian Ocean T. minor, and the new tropical species T. patbergquistae found in northern Western Australia, Northern Territory and the Great Barrier Reef, Queensland.

Tetrapocillon species are cryptic due to their very similar external morphological features with the genus containing only encrusting or small lobate sponges. In Australia Tetrapocillon novaezealandiae and $T$. patbergquistae are the thickest species, up to 40 and 50 $\mathrm{mm}$ thick, and T. minor the thinnest, up to $10 \mathrm{~mm}$ thick only. Tetrapocillon kurushimensis was described by Tanita (1961) as a thin encrustation of $1 \mathrm{~mm}$ over worm tubes, and T. atlanticus is $2-4 \mathrm{~mm}$ thick (Van Soest 1988). Tetrapocillon novaezealandiae and T. minor have black external surfaces when alive, $T$. patbergquistae is grey or black externally, T. atlanticus is pale yellow, and the live colour of T. kurushimensis was not recorded. All species of Tetrapocillon have very similar skeletal complements of weakly developed skeletal tracts (Van Soest 1988), with no marked ectosomal specialization except for spicule fans at the surface and pigment cells in the species with black surfaces. They are difficult to separate on internal skeletal and spicule characters with species having either styles as megascleres ( $T$. novaezealandiae, T. minor, T. patbergquistae and $T$. kurushimensis) or strongyles (T. atlanticus). Due to these limited morphological characters molecular studies would assist with understanding phylogenetic relationships between the species and clarify the number of species occurring globally.

The genus contains a unique microsclere, the tetrapocilli, which occurs in all species. In some species the tetrapocilli have two morphologies, called here splayed and regular. In Tetrapocillon novaezealandiae and $T$. patbergquistae these forms are in two size categories while in $T$. minor they are of similar size. Tetrapocillonatlanticus also has two size categories of tetrapocilli (Van Soest 1988), but Tanita (1961) did not report size classes in T. kurushimensis.

Van Soest (1988) described spined isochelae in Tetrapocillon atlanticus. These microscleres were found in all three species reported from Australia, and are referred to here as acanthoisochelae. Tetrapocillon minor was not described with isochelae and we could not see them in two microscope slides which are the only type material remaining after the loss of the holotype specimen. However, all new material from Tanzania, Madagascar and Western Australia have tiny isochelae, visible with SEM, but not with light microscopy. Lévi (1963) reported isochelae in T. novaezealandiae and we have found two morphologies of isochelae in this species with SEM. Tetrapocillon patbergquistae also contains isochelae with shallow concave alae, clearly different from those reported in all other species. Tetrapocillon kurushimensis was not reported with isochelae, however if these microscleres are small, SEM will be required to detect and describe them. Detailed study of microscleres with SEM greatly assisted our ability to separate the three species of Tetrapocillon occurring in Australia.

We found acanthoisochelae in a transitional series from regular palmate to those with rudimentary alae that were sigmoid and occasionally almost circular in T. minor. Acanthoisochelae have been found in species of the sister genus Guitarra and are here considered a synapomorphy for the closely related genera Guitarra and Tetrapocillon. Some species of Guitarra have been described with sigmas. Fromont and Bergquist (1990) discussed the need to determine when a sigma is truly a sigma, to be certain of the homology of the characters being examined, before relationships between taxa are inferred. This study suggests that it is essential to examine Guitarra 'sigmas' in detail in future to determine if they are true sigmas or are transitional from isochelae, such as we found here in T. minor.

The type specimen of T. kurushimensis was preserved in formalin and is stored dry. Tanita (1961) indicated that two individuals of T. kurushimensis occurred on different parts of worm tubes, but only parts of these tubes are in the Museum collections in Ibaraki. We were provided with two fragments from different parts of the tubes (NSMT Po 1121) for histological processing and examination. However, we could not find material of Tetrapocillon. One fragment contains spicules of a species of Zyzzya and the other had poecilosclerid spicules of various forms.

The distributions of both Tetrapocillon novaezealandiae and $T$. minor were found to be largely disjunct. Population genetic studies along the range of distribution of these species are essential to determine whether or not they represent two complexes of cryptic species. To date we have found no diagnostic morphological features that allow the separation of the different populations of $T$. novaezealandiae across the Southern Ocean, or T. minor in the Indian Ocean, into additional species. Limited collecting has been undertaken in these locations and with future collecting these distributions may become more contiguous or characters to distinguish cryptic speciation may be found.

There are now five species of the genus described globally, the above three species and Tetrapocillon kurushimensis Tanita, 1961 and T. atlanticus Van Soest, 1988. We confirmed during this study the presence of the genus in Hawaii (O. Tendal, pers. comm., J. Hooper, pers. comm.). Further material assigned to the genus Tetrapocillon from Chuuk, Davao and Fiji is also available in the collections of CRRF suggesting that the genus is well represented through the Central and Eastern Indo-Pacific. It was beyond the scope of this study to determine whether or not this additional material is conspecific with any of the known species or if they represent undescribed species. The material from Papua New Guinea described by Pulitzer-Finali (1996) as T. minor (MSNG 55060) requires allocation to a new 
species and it may be conspecific with some of the IndoPacific species yet to be studied. The genus is therefore much more widespread than previously reported and it is possible that at least nine species could occur globally. Further studies in other parts of the world on this enigmatic genus are warranted.

\section{ACKNOWLEDGEMENTS}

Sample numbers prefixed with $0 \mathrm{CDN}$ and $0 \mathrm{M} 9 \mathrm{H}$ codes were collected for the United States National Cancer Institute, under the 'Collection of shallowwater organisms' programme, by Coral Reef Research Foundation (CRRF Contract N01-CM-27704 and N02-CM-77249) and the Museum and Art Gallery of the Northern Territory (subcontracted through CRRF Contract N02-CM-27003). Dampier specimens were collected during the Western Australian Museum/ Woodside Energy Ltd partnership 1998-2002 by the Western Australian Museum, and the Dongara specimen from the SRFME funded project 'Biodiversity of Marine Fauna on the Central West Coast' (SRFME project no. 3.3.7) also by the Western Australian Museum. Our colleagues provided invaluable assistance with access to material and/or critical information and we thank the following for their assistance: Guiliano Doria, Museo Civico di Storia Naturale, Genova; Bruce Marshall, Museum of New Zealand Te Papa Tongarewa, Wellington; Hiroshi Namikawa, Showa Memorial Institute, National Museum of Nature and Science, Ibaraki; Merrick Ekins and John Hooper, Queensland Museum, Brisbane, Rob Van Soest and Elly Beglinger, Zoological Museum of the University of Amsterdam, Amsterdam; Ole Tendal, Zoological Museum, State National History Museum of Denmark, University of Copenhagen, Copenhagen; Lori Collin, Coral Reef Research Foundation, Palau. We also thank Ellie Hayward, Charles Darwin University, Darwin, for her assistance with SEM and two reviewers for comments on this paper.

\section{REFERENCES}

Bergquist, P.R. and Fromont, P.J. (1988). The marine fauna of New Zealand: Porifera, Demospongiae, Part 4 (Poecilosclerida). New Zealand Oceanographic Institute Memoir 96: 5-138.

Borgo, E., Brunetti, M. and Raineri, V. (1998). Elenco dei Poriferi della collezione del Museo Civico di Storia Naturale 'G. Doria' di Genova. Annali del Museo civico di Storia naturale Giacomo Doria 92: 311-392.

Boury-Esnault, N., Pansini, M. and Uriz, M.-J. (1993).
Cosmopolitism in sponges: The 'complex' Guitarra fimbriata with description of a new species of Guitarra from the northeast Atlantic (pp. 367-373). In: Uriz, M.J. \& Rützler, K. (eds), Recent Advances in Ecology and Systematics of Sponges. Scientia Marina 57(4): 273-432.

Bowerbank, J.S. (1864). A monograph of the British Spongiadae. Volume 1. Ray Society: London.

Brøndsted, H.V. (1924). Papers from Dr. Th. Mortensen's Pacific Expedition 1914-16. 23. Sponges from New Zealand. Part 1. Videnskabelige Meddelelser fra Dansk naturhistorisk Forening 77: 435-483.

Carballo, J.L. and Uriz, M.J. (1998). Guitarra flamenca sp. nov. (Porifera: Poecilosclerida) with a SEM revision of the spiny isochelae and placochelae in the genus. Journal of the Marine Biological Association of the United Kingdom 78: 807-819.

Carter, H.J. (1874). Descriptions and figures of deep-sea sponges and their spicules from the Atlantic Ocean, dredged up on board H.M.S. 'Porcupine', chiefly in 1869; with figures and descriptions of some remarkable spicules from the Agulhas Shoal and Colon, Panama. Annals and Magazine of Natural History (4) 14(79): 207-221, 245-257.

Dendy, A. (1916). Report on the non-calcareous sponges collected by Mr James Hornell at Okhamandal in Kattiawar in 1905-6. Report to the Government of Baroda on the Marine Zoology of Okhamandal in Kattiawar 2: 93-146.

Fromont, J. and Bergquist, P.R. (1990). Structural characters and their use in sponge taxonomy: when is a sigma not a sigma? (pp. 273-278). In: Rützler, K. (ed.) New Perspectives in Sponge Biology. Smithsonian Institution: Washington D.C.

Hooper, J.N.A. and Wiedenmayer, F. (1994). Porifera (pp. 1-624). In: Wells, A. (ed.) Zoological Catalogue of Australia. Volume 12. CSIRO Publishing: Melbourne.

Lerner, C., Hajdu, E., Custódio, M.R. and Van Soest, R.W.M. (2004). Guitarra sepia n. sp. from the Southwestern Atlantic (Demospongiae, Poecilosclerida, Guitarridae). First record of a Guitarra without placochelae. Bolletino dei Musei e degli Istituti Biologici dell'Università di Genova 68: $405-411$.

Lévi, C. (1963). Spongiaires d'Afrique du Sud. (1) Poecilosclerides. Transactions of the Royal Society of South Africa 37: 1-72.

Pulitzer-Finali, G. (1993). A collection of marine sponges from east Africa. Annali del Museo civico di Storia naturale Giacomo Doria 89: 247-350.

Pulitzer-Finali, G. (1996). Sponges from the Bismarck Sea. Bolletino dei Musei e degli Istituti Biologici dell'Università di Genova 60-61: 101-138.

Soest, R.W.M. van (1988). Tetrapocillon atlanticus n.sp. (Porifera, Poecilosclerida) from the Cape Verde Islands. Beaufortia 38: 37-46.

Tanita, S. (1961). Report on the sponges collected from the Kurushima strait, Seto inland sea. Memoirs of the Ehime University 4: 337-354.

MANUSCRIPT RECEIVED 7 DECEMBER 2009; ACCEPTED 4 MARCH 2010. 